\title{
Representation of Indigenous Women in Contemporary Aboriginal Short Stories of Australia and India: A Study in Convergences and Divergences
}

Indranil Acharya

Vidyasagar University, West Bengal, India

\begin{abstract}
This paper tries to review and reassess the tribal situation with special reference to the tribal women in India and Australia. It is an attempt to locate the 'Aboriginal woman' question in the context of women's movement in both countries. In Australia the women's movement, on the whole, has not been successful in incorporating Aboriginal women into its concerns and activities. Relations with Aboriginal women have constituted a problem with the women's movement. Despite many differences in socio-cultural set up the stories of Anil Gharai and those of Australian Aboriginal writers share many common traits and cut across cultural differences. It establishes the theory of pan-aboriginality that exists in countries that possess a sizeable population of indigenous people.
\end{abstract}

The term 'tribal' was applied by the British colonizers and missionaries to comprehend and narrate the lifestyle of indigenous people they encountered in Africa, Asia, Australia and the new world. The people living in dense forests or remote inaccessible hillsides were called tribals to differentiate them from other civilized people. The term 'Aborigine' or 'Aboriginal' is much more familiar than the term 'tribe' in Australia. The word means 'the people who were here from the beginning'. Aborigines are Australia's indigenous people who form nearly 2.4 percent of Australia's total population (1996 census) whereas tribal population (Adivasis) in India forms about 8.1 percent (1991 census). Recent researches in social science have registered some linguistic and genetic similarities between India and Australian Aborigines. In this paper, it has been my persistent attempt to review and reassess the tribal situation with special reference to the tribal women in India and Australia. I have also tried to locate the 'Aboriginal woman' question in the context of women's movement in both countries. In Australia the women's movement, on the whole, has not been successful in incorporating Aboriginal women into its concerns and activities. Relations with Aboriginal women have constituted a problem with the women's movement.

In recent years women's movement has accepted theoretically the issue of racial differences between women, and there is some evidence of concerted

Rupkatha Journal on Interdisciplinary Studies in Humanities (ISSN 0975-2935)

Volume I, Number 2, Autumn 2009

URL of the Issue: www.rupkatha.com/journalvol1no2.php

PHP URL of the article: www.rupkatha.com/aboriginalshortstories.php

PDF URL of the article: www.rupkatha.com/0102aboriginalshortstoriesaustraliaandindia.pdf

(C) www.rupkatha.com 
practical efforts on the part of the white women's movement to break down the barriers of black and white sisterhood. Women's refuges are now serving on Aboriginal women more since Aboriginal women have been employed as refuge workers, in contrast to the situation on Alice Springs in 1980 when some white women refused black women access to the women's refuge. ${ }^{1}$ Incidents such as this were not typical of women's movement. Most of its activists were expressly anti-racist, yet contact with black women was very limited. The failure to incorporate black women was hardly surprising, for the women's movement was an expression of white Australian female society.

In feminist ways, the women's movement made the racist mistake of thinking that they knew what a black woman wanted. In researching black women's responses to the women's movement, Meredith Burgmann found ample evidence of 'their sense' of alienation from yet another white-organized, whitedominated movement with white values and white concepts. ${ }^{2}$ Bobbi Sykes admits to some 'mutually beneficial exchanges' with the white women's movement. But the exchanges were lopsided. The whites were in the position of 'helper' and the aboriginal women in the position of 'helped':

The power relationship that exists between the white community and the black community exists also in the relationship between white women and black women. Black woman, sensitive to the feeling of embarrassment which always being the inferior party in the helper/helped dyad creates... practice politically motivated avoidance of the women's movement. ${ }^{3}$ The white women's movement, to black women, is simply a struggle between the two white sexes that both oppress all black people. Black women regard their race rather than their sex as the principal source of their exploitation and oppression. They feel solidarity with their black menfolk against white people of both sexes. They do not feel a solidarity/sisterhood with white women. ${ }^{4}$ As Bobbi Sykes observes:

...in comparison to both black women and black men white women are extremely powerful and have control over many resources ...White women own level, and stand to inherit land - level of which the black community has been dispossessed. White women have gained from every massacre of black people, whether directly or indirectly. ${ }^{5}$

For Eve Fesl, white women are far greater oppressors of black women than black men have ever been. ${ }^{6}$ 
Some of the demands of the white women's movement are in direct conflict with the interests of black women. For instance, black women have long been fighting against enforced sterilization from white doctors and struggling not to have their babies taken away from them, to have healthy children and keep them, not to get rid of unwanted pregnancies. In fact, WAAC included 'No forced sterilization' in its list of demands, noting that in many areas of Australia, Aboriginal women are sterilized without their consent ${ }^{7}$. But this aspect of the campaign was never stressed and black women's understanding of the women's movement was refracted through the media, which tended to present the movement as being pro - abortion rather than merely pro - choice. Likewise, the women's liberation slogan of 'smash the family' was meaningless to Aboriginal women, who had battled for nearly two centuries against the white authorities who wished to break up Aboriginal families, to remove Aboriginal children from the care of their Aboriginal mothers. As for the demand for sexual freedom, Roberta Sykes has pointed out that black women have had sexual freedom, socalled, forced upon them for centuries, and by white men not by black men. ${ }^{8}$

When black women confront problems within their own communities, such as domestic violence, the approach is not a woman-against-man approach. Koorier recently publicized Charles Perkins' address to their National Workshop on Domestic Violence: 'domestic violence must be viewed in the more general context of Aboriginal social and economic disadvantage; strategies for approaching the problem must be community based and involve community members and be closely linked to general strategies for Aboriginal advancement. ${ }^{9}$ Black women clearly feel this is a problem to be solved with black men, not with white women. Hilary Saunders has summed up the feelings of many black women:

We must not let this awareness as women go too far: We are a race of people who have suffered many injustices. We are fighting for selfdetermination. Women must play a large part in this yet we can only hope to achieve this as one people not a race of men, nor a race of women but of Black United People. ${ }^{10}$

Bobby Sykes maintains that 'the division of the black community along sex lines can only weaken our already unenviable position and may, in fact, spell doom to all of our black people. ${ }^{11}$ Pat O'Shane has commented that 'when the white 
women's movement takes head-on the struggle against racism, which is the greatest barrier to our progress, then we've got a chance of achieving sisterhood.' 12

As we try to read an Aboriginal story, Paddy Roe's 'Worawora Woman', issues like scope and extent of sexual freedom and domestic violence crop up inevitably. The protagonist is a strong man whose curiosity leads him to the Worawora woman and who becomes responsible for his inability to feed his wives. Finally he has to behead the woman so that he can return to normality. It is only then that he can take food for his wives and his married life is restored.

One day he thought he'd see if the Worawora woman really existed, so he painted himself up in the required way. He left his camp and went to the right tree where the woman came out to meet him.

They hunted together, but when he wanted to share the hunt between her and his women in camp she refused, taking all the food for herself.

The man went back home empty-handed. His wives questioned him, he said he could find nothing.

Every day he went to this woman and the same thing happened. Eventually he revealed the truth at his wives' insistence. ${ }^{13}$

Then he went and decapitated the woman. The urgent need for consolidating familial ties ultimately forced the man to give up his freedom of spending time with his woman of choice.

The upholding of family at the expense of extramarital relationship should also be viewed from the standpoint of Aboriginal social and economic disadvantage. The problem is typically community based and the conflict between individual need and collective need clearly shows the nature of distraction created in the harmonious social setting by the call of instinct.

Joe Nangan and Hugh Edwards' 'Bara, the Sun Maidens' is a reported oral narrative that speaks of history in mythical dreamtime. Though rooted in remote past the Aboriginal male role as hunter and aggressor is challenged by the presence of mighty female figures- the sun maidens. Any attempt at violating the inviolable beauty of the mythical women would inevitably lead to death and destruction. Certain sacrosanct ideals of Aboriginal society are preserved from male gaze and subsequent onslaughts of desire. 
In the Dreamtime days, far, far in the East, where the realm of Bara, the sun lies, the Sun girls used to live. They were very beautiful - far more beautiful than any ordinary women - but it was death to touch them because their shining, in candescent skins gave out more heat that any man could bear to touch and still live. ${ }^{14}$

Two young warriors of the Nygina community, both 'bungana' i.e. young unmarried men at a particular stage of initiation, moved to see the Bara girls. They paid no heed to the warnings of the elder - "There is death in the sun if you go too close." But when they saw the exceeding beauty of the Bara girls bathing in a billabong they were intoxicated by the sight and were heedless of the warnings.

"Come," they cried again, "come to our country in the West," and, forgetting all the warnings of the elders, they ran down the hill towards the billabong. "Aieeh", cried the Sun girls, and tried to run away. But the foolish warriors seized two of them and tried to take them by the billabong. At that moment they fell dead, seared by the enormous heat from the girls' shining bodies. ${ }^{15}$

Thus, in the context of mighty female presence and resultant male dissolution it becomes quite apparent that the collectivity and belongingness of Aboriginal mythical women are indispensable to their presentation of themselves as subjects. Unfortunately, western feminism cannot address such issues pertaining to Aboriginal women because of its complicity in the subjugation of the indigenous women.

In India, several Dalit writers have expressed their profound dissatisfaction over the women's movement in India and its domination by upper caste women who carefully gloss over the particular problem of tribal women's oppression. In Bengal, the sole authentic voice representing the trials and tribulations of the downtrodden tribals is that of Mahasweta Devi. In some poignant stories like 'Draupadi', 'Choli ka peechhe' and 'Hulmahar Maa', she has depicted with great insight and feeling the pangs of survival experienced by tribal women. 'Subachani', a story by Bhagirath Mishra also reveals the dark face of so-called civilized society through a narration of the untold sufferings of a tribal woman. Many young writers of the upcoming generations are now writing about 
tribal life and problems. In the limited space of my paper I have decided to focus my attention on Sri Anil Gharai, a representative Dalit writer.

In the stories of Anil Gharai, a contemporary Bengali writer of indigenous origin, the struggle for existence is reflected in its barest form. As a telecommunications engineer, posted at South Eastern Railways' Chakradharpur microwave station, Gharai saw the poverty - stricken tribals of Singbhum district from very close quarters for many years. His interaction with the tribals who lived near his residence in Chakradharpur was a sustained give-and-take process. $\mathrm{He}$ spent all his free time with them, armed with a notebook. "I learnt a lot from their life-style. Their simplicity inspires me" says Gharai. ${ }^{16}$

The genuine empathy with the downtrodden which imbues his stories prevents them from degenerating into diatribes. Gharai speaks of the boundless energy and zest for life he sees in the midst of poverty and deprivation: "Exploitation is a double-edged sword - it comes as much from outside as from within the tribal society. So I avoid pointing fingers. My job is to highlight what I see." 17

Exploitation within tribal society should be viewed, as in Australian Aboriginal society, in the more general context of tribal social and economic constraints. And the strategies for solving the problem should be community based and involve community members. But the more powerful threats are often posed by the outside world. Anil Gharai's 'Stories of the Downtrodden' speaks of this rural tribal India and its folks and each story brings out a particular section of society to the forefront.

The anthology breaks through barriers of caste, creed and religion to present the suffering voices. The characters speak for themselves, like the poor tribal girl Habhati in 'The Almond Flowers'.

She breaks down completely when she is raped by the 'babus' who had come to her father's land to graze their cattle. She could not ever resist when his father sold her beloved almond flowers to those babus for some money. She refuses to show her face to the 'sepoybabu' whom she loved and had thought to marry one day. Habhati feels that she has lost everything, her love and also her almond flowers.

Habhati walked quickly. Suddenly the lamp went out. A strong hairy hand pulled her into the bushes. She tried to scream but could not. 
The wind carried a faint groan but it could not be heard. The cicada flew away in fear. The fox was around to see everything. It had sharp nails yet it did nothing.

Habhati's sari floated on the air. Somehow she arranged to wrap it around but failed to do so. She fell at the feet of the strong and hefty man. He did not push her away. But in an indifferent and cold manner he said, "Your father wanted manure, I gave it. Go back home. There will be crops."

Taking up the container, the man walked towards the fields. He turned back and said, "If you speak about this I will kill you. Go home."18

Life after this unfortunate event was intolerable for Habhati. She was crestfallen and lost all faith in men she also panicked at the prospect of her favorite almond tree.

Habhati looked around in grief and dismay. She looked at the tree in a strange manner. She wouldnot cry, not in front of everybody. She swallowed hard and looked at her father again. He tried to make her understand, "These are jungle flowers, no smell; nothing of what use is it? Give it to the babus, they will be pleased." Habhati broke branch after branch of the red flowers. The young man laughed...

When 'sepoybabu' returned there was not a single flower left. Looking at the tree bereft of flower and leaves of beauty, he could not see their sky. He could not see the fairy land's sky. He only saw Habhati crying and sobbing. Her face was red - so much like the almond flower soaked-in dew. ${ }^{19}$

Gharai's other heroine Bindiya, in an eponymous short story, is a beautiful and young tribal 'banjara' woman. She shows rare courage when she takes up her battle against the policeman who had wanted some intimacy with her. She had seen how women of her clan were exploited physically by the policemen. So instead of conceding to the man's demands, she decides to fight it out. She lures the policeman into her trap and kills him. She not only saves her own skin, but saves many other women from disgrace. Bindiya's courage is quite different from Habhati's lonely figure. It is chiefly because Habhati has to fight against an enemy inside his effete yet greedy father who does not even mind the loss of virginity of his daughter. Yet there is an eternal bond shared by the two women. 
Both of them represent the hundreds of tribal women who are exploited every day in a society that cares little for them because they happen to be poor.

The policeman's face burnt like a brand and his warm breath spread over Bindiya who was absolutely cold. Her blood was boiling and she regarded the policeman as the symbol of persecution to which she and others like her had been subjected. Munni had said good bye to the proud world. But she would not give up the struggle so easily.

At long last, after what seemed an eternity, it was all over, Bindiya drew out the knife from her corset. What Munni could not do, Bindiya did that perfectly. The silence of the tranquil night was shattered as the policeman rolled over crying out in pain. Blood ran over his thighs, something which had adorned only the Munnis' and the Lachmis' and the rest like them. ${ }^{20}$

To conclude, the stories of Sri Gharai have manifested a keen desire for the downtrodden women who take up their cause with surprising boldness. He has long been writing about the marginalized women. He writes about the voiceless section of the society. He is a writer of commitment and integrity. Despite many differences in socio-cultural set up the stories of Sri Gharai and those of Australian Aboriginal writers share many common traits and cut across cultural differences. It establishes the theory of pan-aboriginality that exists in countries that possess a sizeable population of indigenous people. At the same time, it should also be admitted that the movement for fulfillment of tribal demands is yet to find a solid footing. The great uprisings led by Birsa Munda or the sacrifices of great tribal figures like Sidhu and Kanu have not been followed up in the true spirit by the later generations. Even the role of SC/ST Commission is increasingly put under scanner. Recent political disturbance in the Western part of West Bengal has been termed by a section of the media as 'Second Santal Rebellion'. It is really difficult to assess the problematic situation with such catchy phrases. However, Indian tribals, unlike their Australian counterparts, are yet to unite for the betterment of their socio-economic profile. Authors like Anil Gharai wonderfully capture the disastrous consequences of the tribal people's failure to consolidate their position even sixty years after Indian independence. 


\section{NOTES}

1. 'Eve Fesl', in Robyn Rowland (ed), Women who do and women who don't join the women's movement, p.15.

2. Meredith Burgmann, 'Black sisterhood: The situation of urban Aboriginal women and their relationship to the white women's movement' in Marian Simms (ed) Australian women and the political system, p.39.

3. 'Bobbi Sykes' in Rowland (ed), Women who do and women who don't, pp.63-5.

4. Jackie Huggins, 'Black women and women's liberation', Hecate XIII,1, p.78.

5. 'Bobbi Sykes' in Rowland (ed), Women who do and women who don't, p.68.

6. 'Eve Fesl', in Robyn Rowland (ed), Women who do and women who don't, p.110.

7. WAAC, 'Demonstrate December 6',leaflet, nd [1975].

8. Burgmann, 'Black sisterhood', p.42.

9. Koorier 3, May 1989, pp.6-7.

10. Quoted in Huggins, 'Black women and women's liberation', p.81.

11. 'Bobbi Sykes' in Rowland (ed), Women who do and women who don't, p.69.

12. Quoted in Burgman, 'Black sisterhood', p.43.

13. 'Worawora Woman' in S.K.Sareen (ed), Contemporary Australian Short Stories, p.112.

14. 'Bara, the Sun Maidens' in S.K.Sareen (ed), Contemporary Australian Short Stories, p.110.

15. Ibid, p.111.

16. Quoted in S.Jana and S.Majhi (eds), Prasanga Anil Gharai, p.457.

17. Ibid, p.457.

18. 'The Almond Flowers' in Anil Gharai, Stories of the Downtrodden, p.22.

19. Ibid, p.23.

20. 'Bindiya' in Anil Gharai, Stories of the Downtrodden, pp.75-6.

\section{WORKS CITED}

Gharai, Anil. Stories of the Downtrodden. Kolkata: Dey's Publishing, 2003.

Jana, S. and Majhi, S. (eds), Prasanga Anil Gharai. Kolkata: Dey's Publishing, 2004.

Rowland, Robyn (ed), Women who do and women who don't join the women's movement. London/Melbourne: Routledge \& Kegan Paul, 1984.

Sareen, Santosh K. (ed), Contemporary Australian Short Stories. New Delhi: Affiliated East-West Press, 2001.

Simms, Marian (ed), Australian women and the political system. Melbourne: Longman Chesire, 1984.

Writer: Indranil Acharya is Senior Lecturer in the Department of English, Vidyasagar University, India. E-mail: Indra_acharya33@yahoo.co.in 